\title{
The Study of the USA in Norwegian High Schools
}

By

Alf Bårtvedt

Bo, Telemark

Those of you who are aquainted with secondary education in Norway know, of course, that we are in a transition period at present. The traditional gymnas, with its academic bias, is gradually being replaced by a new comprehensive secondary school resembling the Swedish pattern. In a way the gymnas survives in the socalled "allmennfagleg studieretning" in the new school, but it is meant to be a wider and more flexible system allowing students and teachers more freedom and personal choice.

This makes it rather difficult to generalize about high schools in Norway at present as different systems exist side by side, and within each of these systems there are different syllabuses in the subject that is the concern of this seminar.

However, for the sake of clarity and simplicity I intend to confine myself to the socalled 'engelsklinja' in the gymnas and the syllabus for those students who choose the most far-ranging English course in the new comprehensive secondary school. In principle, these plans coincide to a large extent and the final objectives are more or less the same.

As teachers of English our chief concern is the teaching of English. Language, communication, is our main task. However, no language exists without a social and cultural context, and to be able to use a language in an intelligent way, you need some understanding of the society in which this language operates. And I suppose this is the raison d'être for including the study of the USA in an English syllabus.

It has been officially laid down that the teaching of English aims at making the students understand and use oral and written English, and that we as teachers of English must convey an under- 
standing of the culture and ways of life of the English-speaking world to our students. It has also been decreed that when the students sit for their finals they should be able to follow a lecture by a native speaker of English and be able to read daily newspapers and fiction in English.

To achieve these aims it is further specified (and I confine myself to the US now) that the students ought to be acquainted with social classes and minority groups, industrialization and urban problems, social security and social problems, the educational system, political parties and federal election?, federal and state power, the various branches of government, and civil rights.

The above-mentioned areas are partly covered by factual prose in the available textbooks, and a specified number of pages dealing with present-day American issues have to be submitted for the final exam. In addition, each student has to study some American literature consisting of extracts, short stories, poetry and a play or two. Some of these texts are set texts, but most of them are chosen by the teacher and his students.

On the whole today's textbooks, whether anthologies of literature or of factual prose, concentrate fairly evenly on the USA and Great Britain. The bias towards Britain is a thing of the past. And all textbooks now in use are reasonably modern and up-to-date as they date from the 1970s and late 60s. To keep them upto-date in future it will be essential to revise them at regular intervals, but for various reasons there is growing opposition to this. Some teachers claim that it gives them too much work and that they cannot possibly cope, whereas students complain that they are commercially exploited by textbook editors and publishers. Some of the texts on America currently being used will obviously he dated in a few years given the present rate of development. So in my view, if we are to concentrate on aspects of a changing America in a satisfactory way we have to accept the necessary expenses that this study entails.

Apart from the financial problems that such study presents, some dangers are involved. As we have, for obvious reasons, to single out a few areas for intensive study, this may only too easily lead to onesidedness. The students generalize on the basis of these isolated, and sometimes controversial, texts, and despite being warned against it, they take these texts to be representative of the US at large. Black and white attitudes and simple solutions to complex problems are very often the result. The students believe that they 
know more and have a deeper insight than they really have. It is my impression that this tendency to take the short cut, to opt for simple and easily-explained solutions, is part of the general intellectual climate at present. Our students want ready-made conclusions and facts that help support preconceived views and attitudes. To generalize one might say that many students hold strong views without having the necessary amount of factual knowledge to support these views.

Let me give you a few examples of the modern kind of illiteracy that $I$ have in mind. I take it that we all agree that isolated facts in themselves are not necessarily of any significance. Nevertheless there are some things we ought to be familiar with if we are to read American news magazines or newspapers, or watch American documentaries on $\mathrm{TV}$ in a meaningful way. It is my guess that a surprisingly large number of Norwegian high school students do not know the name of the American President. This may, of course, not be so bad as it sounds, but it is highly likely that the same students, and even more, would know next to nothing about the Executive Office and what sets this apart from, say, the office of the British Prime Minister. Very few are able to distinguish between state and federal government, although this is explicitly mentioned in the curriculum, and geographical knowledge of the USA is scanty at best. The South and South America, for example, are often regarded as more or less the same area. And misconceptions abound. Some believe that Negro slavery lasted until the Civil Rights Legislation of the mid-60s, and most students are convinced that black Americans did not win the right to vote until a decade ago.

Sometimes such widely held notions come as no surprise at all, because it is the unusual, the striking event, which hits the headlines and is covered by radio and TV. And the more you hear about this and the more you read about it in your textbooks, which you increasingly do, the more you come to believe that life is like that.

I would like to bother you with an example based on personal experience to illustrate my point.

My first and so far only visit to the USA took place in the summer of 1974. For personal and professional reasons I have always taken some interest in American affairs and much of my second-hand impression of the US was based on the mass-media and their coverage of the Civil Rights Movement, the youth revolt, the urban crisis and growing crime, pollution, the War in South-East Asia and Watergate to give a few key words. I have to admit that 
my anticipations were not the best before venturing on a sevenweek stay in the USA. However, I soon realized that I had to revise my somewhat gloomy view. Life in America was not as bad as I had been led to expect. To my great and pleasant surprise Chicago and New York were about just as human or inhuman as any other large city I had visited. There is much crime, true; there is pollution - in short, there are problems. But everyday life is by no means so chaotic and dehumanized as we often tend to conclude from our side of the Atlantic.

Now, you who have travelled much more extensively in the USA and who also have a much deeper knowledge of America and Americans than I have, you may, of course, dismiss me as a somewhat naive hillbilly who was easily fooled, first by the news media and then by what he superficially observed in the USA. But my point is that if $\mathbf{I}$ was taken in by what $\mathbf{I}$ had read and heard about the USA, what then is likely to happen to the average high school student when he is confronted with the complex social, racial and political issues of today as presented by our textbooks and by the mass-media?

Finally, I want to turn from the distortion that is frequently the consequence of reading controversial texts to the teaching of language.

Some students are unable to differentiate between American and British English. American spelling is retained in American texts in our textbooks, and tapes recorded by native speakers accompany some of these texts. The students take after this and tend to mix British and American English in their written and oral work. My personal attitude is that we should not spend too much time and energy on distinguishing between the two. The kind of English we are going to use will always be affected by our Norwegian background, and in my view we ought to aim at a written and spoken standard that works in an international context. If this turns out to be a mixture of $\mathrm{AE}$ and $\mathrm{BE}$ it is all right with me. After all we have to be pragmatic, not dogmatic. And we ought to bear in mind that very few of our students are going to take up further studies of English at the university level. Our task is to enable as many as possible of the others to use the English language to serve their ends, which may be the reading of newspapers and news magazines, studying books related to their line of business, or simply watching TV or films. 